LAW, ETHICS, AND MEDICINE

\title{
A covenant with the status quo? Male circumcision and the new $B M A$ guidance to doctors
}

M Fox, $M$ Thomson

See end of article for

authors' affiliations

J Med Ethics 2005;31:463-469. doi: 10.1136/jme.2004.009340

Correspondence to:

Michael Thomson, School

of Law, Keele University,

Staffordshire ST5 5BG

UK; m.o.thomson@keele.

ac.uk

Received 12 May 2004

In revised form

19 August 2004

Accepted for publication

31 August 2004
This article offers a critique of the recently revised BMA guidance on routine neonatal male circumcision and seeks to challenge the assumptions underpinning the guidance which construe this procedure as a matter of parental choice. Our aim is to problematise continued professional willingness to tolerate the non-therapeutic, non-consensual excision of healthy tissue, arguing that in this context both professional guidance and law are uncharacteristically tolerant of risks inflicted on young children, given the absence of clear medical benefits. By interrogating historical medical explanations for this practice, which continue to surface in contemporary justifications of non-consensual male circumcision, we demonstrate how circumcision has long existed as a procedure in need of a justification. We conclude that it is ethically inappropriate to subject children-male or female-to the acknowledged risks of circumcision and contend that there is no compelling legal authority for the common view that male circumcision is lawful.
I recognition of the growing controversy surrounding neonatal male circumcision, the British Medical Association's Medical Ethics Committee released new guidance for doctors in 2003. ${ }^{1}$ This is the first professional pronouncement in the UK since the General Medical Council's guidance in 1997.2 Upon its publication, the Journal of Medical Ethics published the BMA's advice along with two, quite starkly opposing, commentaries. ${ }^{3}{ }^{4}$ This article offers a brief assessment of the BMA's response to the practice of neonatal circumcision, and suggests that certain assumptions underpinning it need to be questioned. In particular, we challenge the legal position represented in the BMA guidance, arguing that the legality of the practice is much less certain than they acknowledge.

Our focus is on the harm/benefit assessment which lies at the heart of the male circumcision debate and is central both to the revised guidance and to ethical debate on the issue. Specifically, we are concerned to problematise the continuing professional willingness to tolerate the non-therapeutic, nonconsensual excision of healthy tissue. We suggest that infant male circumcision is characterised by an acceptance of levels of risk unimaginable in other health care contexts. In seeking to account for the permissive medicolegal attitude to this practice we argue that it is grounded in particular understandings of the male infant body. We see two (related) issues as central to the debates. First, we examine how risk to the infant male body is understood and managed within the debates, and secondly how this informs the way in which male circumcision is constructed in opposition to female genital modification. The infant male body is conferred with particular qualities that inform and limit the nature of the debate, and the way in which law approaches it.

\section{The guidance-an overview}

The guidance that the BMA offers is in many respects welcome, and brings the UK position into line with recent revisions in other common law jurisdictions. ${ }^{5}$ Thus, it stresses that circumcision is rarely clinically indicated and that "doctors should be aware of this and reassure parents accordingly" (p. 3). ${ }^{1}$ Perhaps more importantly, it states that non-therapeutic circumcision should be performed only when it is demonstrably in the best interests of the child.
The responsibility to show this falls to his parents. ${ }^{1}$ Additionally, the guidance provides principles of good practice, although most of these should already be familiar to anyone working professionally with children. ${ }^{1}$ Thus, they note the paramountcy of child welfare and the need to act in the child's best interests; the need for consent (from either parent where the procedure is therapeutic and from both where the procedure is non-therapeutic-see below); the importance of including the child in the decision making process where possible; and the circumstances where court referral would be appropriate. It is recognised that good practice also demands accurate and contemporaneous record keeping in relation to the discussion, consent, the procedure, and aftercare given.

Yet, the BMA's position is not unproblematic. While reflecting shifts that have occurred in the development of children's rights and evidence-based medicine, it nevertheless largely condones current practice, so that a parental request motivated by social, cultural, or religious justification is likely to validate non-therapeutic male circumcision. In this article we argue that the BMA is able to sanction such requests only because it assumes a particular understanding of the male child's body, an understanding shared by law. Before exploring this, it is worth briefly to outline the origins of non-therapeutic, non-religious practice, and to examine the justifications for it.

\section{Origins}

Although a full history of the emergence and subsequent development of circumcision within medicine is beyond the scope of this article, an outline of the evolution of the practice offers an important context to the current debate. The BMA guidance makes limited note of the problematic history of medical practice in this area. It recognises, for instance, the significant misdiagnosis and mistreatment of phimosis, an abnormal tightening of the foreskin that limits normal function. As the guidance notes: "Male circumcision in cases where there is a clear clinical need is not normally controversial. Nevertheless, normal anatomical and physiological characteristics of the infant foreskin have in the past been misinterpreted as being abnormal" (p. 2). ${ }^{1}$ We would 
contend that the troubled history of medical practice in this area merits fuller recognition.

The emergence of clinical circumcision owes much to the work of the eminent American orthopaedic surgeon Dr John Lewis A Sayre. Sayre's first case involved the treatment of a 5 -year-old for partial paralysis. In 1870, and following a number of further successful operations, he informed his colleagues that circumcision was the answer to a range of ailments: "Many of the cases of irritable children, with restless sleep, and bad digestion, which are often attributed to worms, is [sic] solely due to the irritation of the nervous system caused by an adherent or constricted prepuce" (p. 210). ${ }^{6}$ This marked the beginning of the rise and rise of phimosis, an ill-defined and fluid pathology, ${ }^{7}$ and the recoding of the foreskin as pathological. Beyond the ailments of children, circumcision came to be seen as a cure for more problematic and elusive illnesses, as Geoffrey Miller notes:

Within fairly short order, circumcision was promoted as a remedy for alcoholism, epilepsy, asthma, gout, rheumatism, curvature of the spine and headache ... paralysis, malnutrition, night terrors, and clubfoot; eczema, convulsions and mental retardation; promiscuity, syphilis, and cancer (p. 527). ${ }^{8}$

This promotion of circumcision in the USA and the UK emerged at the same time as a rekindled interest in cliterodectomies and other experiments in sexual surgery. Significantly, both male and female circumcision were justified in terms of managing sexuality; yet, while cliterodectomies soon declined, with other forms of female genital mutilation eventually becoming a focus for domestic and international outrage, male circumcision became routinised in medical practice. In large part this was attributable to the belief that male circumcision cured masturbation, an accepted cause of degeneracy and insanity. Circumcision allowed the Victorians to manage cultural anxieties that had prompted an extensive campaign against masturbation. ${ }^{7}$ Although this was a transatlantic phenomenon it should be noted that anxieties ran higher in the USA. As Hodges notes:

American doctors saw sexuality as more of a threat to public health and social stability than did their European contemporaries. The American medical profession's intense focus on sexuality was due in part to economic pressures, the lack of a rigidly defined class system, the rise of the middle class, the rise of immigration, and other sources of social tension (p. 41). ${ }^{7}$

It was forcefully argued that circumcision diminished the incidence of masturbation by removing or preventing adhesions that would otherwise lead to the penis being handled, and hence to self-abuse. ${ }^{8}$ Arguably, curing masturbation was understood as the most important health benefit of circumcision. ${ }^{8}$

Another key factor was the stigma created through the linkage of those with an uncircumcised penis with disease, pollution, and contagion. In professional and lay publications of the time the foreskin is typically characterised as "a harbour for filth" (p. 769)':

Indeed, anyone who has taken the trouble to compare the dry, pink-parchment-like, cleanly appearance of the glans of the circumcised with the sodden, swollen, uncleanly structure which is frequently presented to view when the prepuce of the uncircumcised is retracted cannot fail to have been struck by the contrast. In the latter case the space between the prepuce and the glans forms the very beau ideal of a place for the implantation and multiplication of bacteria of all kinds, the pent-up secretions furnishing them with an efficient nutrient medium in which to grow, the heat and moisture favoring their development, and the excoriations which are so liable to exist forming a ready means whereby their products may gain access to the general circulation (p. 1870). ${ }^{10}$

This association helps to explain the shift evident from the 1880s onwards towards cleanliness as a justification for circumcision. In 1914 Abraham Wolbarst argued for universal circumcision as a "sanitary measure" (p. 92), ${ }^{11}$ concluding that "the vast preponderance of modern scientific opinion on the subject is strongly in favor of circumcision as a sanitary measure and as a prophylactic against infection with venereal disease" (p. 95). ${ }^{11}$ This shift occurred within a social move that saw cleanliness identified with good morals, and stigmatised the uncircumcised as not only unclean but-by association - of questionable morals. ${ }^{12}$ In these terms Szasz locates circumcision within his model of the "Therapeutic State", a political system where "social controls are legitimised by the ideology of health". In this model, circumcision is emblematic of the "same puritanical zeal for health-asvirtue that has fuelled other typically American crowd madnesses, such as Prohibition, the War on Drugs, and the Mental Health Movement" (pp. 140-1). ${ }^{12}$ Intimately tied to these discourses of cleanliness and morality, during this period circumcision became embedded as a signifier of class and racial differences. ${ }^{13}$ By 1910 it was the most common operation in the USA, ${ }^{8}$ and a routine one in the UK.

\section{Risky practices and the construction of "harm"}

For all that they now seem spurious, the historical justifications for neonatal male circumcision served to obscure the violence inherent in the practice and the risks it necessarily entailed. Although traditionally male circumcision was characterised as a neutral and risk free practice, more recently there has been a growing attention in the ethical literature to questions of risk. ${ }^{14}{ }^{15}$ The BMA's new guidance thus reflects contemporary law and practice by attaching greater weight to risks. As numerous commentators have attested, throughout health care law, and indeed wider social theory, risk is becoming a pervasive theme. ${ }^{16}$ In particular, debates about the law's role in regulating violence against the person are increasingly framed in terms of risk and danger. ${ }^{17}$ However, although the guidance foregrounds risk discourse, it also highlights the contested nature of the risk-benefit analysis. At various points evidence for the supposed beneficial effects of circumcision is described as "equivocal" (pp. 2,4), "inconclusive" (p. 4), " "not convincingly proven" (p. 5), " "contradictory" (p. 7), ${ }^{1}$ causing "significant disagreement" (p. 7), ${ }^{1}$ lacking consensus ${ }^{1}$ and, ultimately, "insufficient" (p. 7). ${ }^{1}$ The BMA concludes that "evidence concerning the health benefit from non-therapeutic circumcision is insufficient for this alone to be justification" (p. 7). ${ }^{1}$ Yet, while this is coupled with a recognition that there are inherent "medical and psychological" (p. 5) ${ }^{1}$ risks in the procedure, the dominant message is still that parental beliefs should be respected despite not being grounded in claims to health benefits:

The medical harms or benefits have not been unequivocally proven but there are clear risks of harm if the procedure is done inexpertly. The Association has no policy on these issues. Indeed it would be difficult to formulate a policy in the absence of unambiguously clear and consistent medical data on the implications of the 
intervention. As a general rule, however, the BMA believes that the parents should be entitled to make choices about how best to promote their children's interests, and it is for society to decide what limits should be imposed on parental choices (p. 3). ${ }^{1}$

A similar position has been defended in the American literature by Benatar and Benatar, ${ }^{18}$ but it is interesting that the BMA's position seems more progressive than that of some liberal commentators such as Margaret Brazier, who provides the following summary:

The child suffers momentary pain. Although medical opinion may not necessarily regard it as positively beneficial, it is in no way medically harmful if properly performed. The community as a whole regards it as a decision for the infant's parents (p. 350). ${ }^{19}$

Although the BMA's recognition of both the equivocal nature of the claimed benefits and the clear risks of harm inherent in the procedure may be interpreted as a more progressive position than some of the liberal commentators, it nonetheless continues to construct male circumcision as an expression of parental privilege. This downplays both the pain experienced by the neonate, ${ }^{1820}$ and the fact that, while complication rates from routine circumcision are low, the chances of these complications being mutilatory, infective, or haemorrhagic are high. ${ }^{21} 22$ Indeed, complications are potentially catastrophic, since death, gangrene, and total or partial amputation are known adverse outcomes. ${ }^{23}$ Yet, the guidance asserts that law legitimises parental choice since nontherapeutic circumcision is "generally accepted" to be lawful (p. 3). ${ }^{1}$ We suggest that legal support for this view is somewhat tenuous, consisting of an obiter dicta comment by Lord Templeman, a Law Commission report, and two cases that tangentially refer to the legality of male circumcision. ${ }^{24} 25$

In Consent in the criminal law, the Law Commission addressed the limits that law should impose on the degree of injury to which a victim might lawfully consent. ${ }^{26}$ It was generally highly critical of the landmark House of Lords' decision in $R$. v. Brown, which criminalised the infliction of injury during consensual sado-masochistic sex. However, it endorsed an obiter comment by Lord Templeman in that case, which lists male circumcision as an example of a deliberately inflicted, but apparently lawful, injury:

Surgery involves intentional violence resulting in actual or sometimes serious bodily harm but surgery is a lawful activity. Other activities carried on with consent by or on behalf of the injured person have been accepted as lawful notwithstanding that they involve actual bodily harm or may cause serious bodily harm. Ritual circumcision, tattooing, ear piercing and violent sports including boxing are lawful activities (pp. 78-9). ${ }^{27}$

The Law Commission concluded that the lawfulness of ritual male circumcision should be put beyond doubt. ${ }^{28}$ To date, Parliament has not legislated, which leaves open the question of whether circumcision is lawful surgery or "proper medical treatment" (p. 109)..$^{29}$ In the main reported case on circumcision-Re $J$ - the judges in the High Court and Court of Appeal confined their observations to the particular point of the dispute, which concerned parental disagreement. ${ }^{24} \mathrm{~J}$, a 5 -year-old boy, lived with his mother, a non-practising English Christian. His father, a non-practising Turkish Muslim, wanted $\mathrm{J}$ to be circumcised so as to identify him with his father and confirm him as a Muslim. The court refused to authorise surgery on the grounds that, since J was not being brought up as a Muslim, he was unlikely to derive any social or cultural benefit from circumcision. It held that, for non-therapeutic circumcision, the consent of both parents would be desirable. However, neither court questioned the assumption that, where parents agree, they should be able to make this decision free of scrutiny.

The Court of Appeal recently followed this approach in the case of Re $S$, which concerned a similar dispute..$^{25}$ A mother applied to the court for her 8-year-old son to be circumcised as a member of the Islamic faith, an application opposed by the child's father. Here, the deciding factors were that the child had been brought up in a predominantly Jain household and the mother's primary motivation for seeking her son's circumcision seemed to be that her new husband was Muslim.

We suggest that a partial explanation of the law's muted response to the risks of infant male circumcision lies in the conceptually fluid nature of "harm". As Carol Smart notes, "harm" is not "a transcendental notion which is automatically knowable and recognisable at any moment in history by any member of a culture" (p. 392). ${ }^{30}$ This conceptual fluidity allows health care law and ethical guidance differentially to construct harms, attaching weight to some, while downplaying others. A key factor in determining how harm is constructed is rooted in understandings of the body that is harmed. For instance, in general, law tends to construct the male body as invulnerable to harm. ${ }^{31}$ By contrast, the female body tends to be characterised by vulnerability, which leaves it more open to medical intervention and management. In relation to children, David Evans notes that modern societies typically construct them as objects of grave concern. ${ }^{32}$ However, we argue that medicolegal responses to harms suffered by children are vexed, and "concern" does not necessarily translate into sensitivity to harms inflicted on them. Since children function as the repository of various contradictory meanings, concern often speaks more to the implications for adults. For instance, other authors, such as Roger Short in his JME article, note that a key motivation for circumcision is often a father's desire that his son physically resembles him. ${ }^{43-35}$ The problem of disentangling familial interests compounds the difficulty in recognising harm to children, such as child abuse, which occurs within the private sphere of the family. In the case of circumcision, moreover, this obstacle is compounded by the way in which religious or cultural practices sanctify the practice of male circumcision.

Additional factors militating against recognition of harm include the age and gender of the child-factors that we argue are crucial in the infant male circumcision debate. Since infants are unable to articulate their harms, they can more easily be ignored, or at least it is more readily accepted that parents are best placed to articulate their interests. More significantly, we argue that the pain and risks to boy infants are downplayed in part because of their place as a rite of passage and signifier of masculinity.

\section{Masculinity and pain}

Within public and legal imaginations there is a dominant understanding of the male body as invulnerable and safe. Cynthia Daniels has explored this in the context of the denial of vulnerability and risk:

In Western industrial cultures, notions of masculinity have been historically associated with the denial of men's physical vulnerabilities and bodily needs and the projection of these characteristics onto the maternal. Men's denial (or dismissal) of bodily risks has been a hallmark of masculine status ... (p. 582). ${ }^{36}$ 
Since the time of ancient Greece, willingness to bodily sacrifice-most notably in warfare-has been one side of a "covenant" that affords men fuller participation in the body politic. Today, as in the past, warfare is met by the sacrifices/ risks of employment, where reproductive and other health hazards are routinely denied or minimised, with the "reward" of higher levels of social, economic, and political participation. This is, of course, shaped by racial and class, as well as gender, differences. ${ }^{37}$

The interplay of sacrifice and masculinity is complicated by the relationship between masculinity and pain. Although pain may be understood as an integral part of the relationship between sacrifice and masculinity, it is related in a wider sense to ideas of masculinity. In her analysis of circumcision, Sarah Waldeck mobilises Timothy Beneke's concept of "compulsive masculinity" - the "need to relate to, and at times create, stress or distress as a means of both proving manhood and conferring on boys and men superiority over women and other men" (p. 57)..$^{38}$ This is relevant in two ways. First, circumcision dovetails with deeply embedded associations between the endurance of pain/distress and proving and defining masculinity. "It'll make a man of you" is articulated in many different ways and in many different locations. This aspect of masculinity is imbricated in a spectrum of "initiation" rites, from early moments of parental blindness to the risks of harm (such as in the case of routine circumcision) through to the tolerance of the homo(anti)sociality of college and military hazing, and ultimately to aspects of our responses to warfare. These arguments may also help to explain why the Law Commission and judges in R. v. Brown ${ }^{27}$ grouped nontherapeutic, non-consensual neonatal circumcision with other activities that are potentially harmful to a consenting (male) adult, such as "manly diversions" and "rough but innocent horse-play" (p. 97). ${ }^{39}$ On this understanding, circumcision is privileged as an early moment that associates masculinity with endurance and pain. Secondly, such cultural associations may well contribute towards the failure to provide adequate pain control for this procedure. Although a wealth of literature highlights the need for pain relief during circumcision, ${ }^{40}$ leading the American Academy of Pediatrics to recommend the use of analgesia, ${ }^{5}$ an "astonishingly large" percentage of infants are circumcised without efficient pain control. ${ }^{35}$ It was estimated in 1999 that $45 \%$ of circumcisions occurred without anaesthetic. ${ }^{41}$ However, a report from the preceding year suggests lower levels of anaesthetic use and, in line with circumcision itself, highlights regional variation:

The debate over whether or not circumcision should be performed seemed to overshadow the fact that between 64 percent to 96 percent of the time babies are circumcised without anesthesia in some areas of North America (p. 20). ${ }^{42}$

It is also worth noting that Benatar and Benatar describe the continued failure to use analgesia as a matter of "great moral concern" (p. 43). ${ }^{18}$ The masculinity/pain nexus may thus be implicated in the continuing practice of routine neonatal circumcision. The BMA's guidance refers to anaesthesia only in the context of consent and knowledge of the associated risks, and the need to provide full resuscitation facilities if general anaesthesia is used. Neither can be read as a statement requiring anaesthesia to be used to minimise pain and discomfort.

Additionally, we would argue that feminist critiques of health care, which have foregrounded harms specific to women, may have contributed to a marginalisation of threats to the male body, a process facilitated by its construction as impermeable. ${ }^{37} 43$ Thus, as Smart notes, boys were seemingly "not constituted as part of the historical story of child sexual abuse" (p. 395)..$^{30}$ This also fits with the tendency of AngloAmerican legal commentators to minimise harms inflicted on boys while exacerbating risks to girls. Certainly this may play some part in explaining the very different stance of both the BMA and English law regarding female circumcision.

Ethicolegal responses to female and male circumcision The differential treatment of male and female genital mutilation is, we would argue, important in understanding the nature of the current debate. This dichotomy is perpetuated by the BMA's practice of issuing separate guidance on the two practices. We suggest that this radical separation partially explains why male circumcision has attracted little medicolegal discussion in comparison with female circumcision, which has "captivated the popular press, the legal academy and the political arena" (p. 725). ${ }^{44}$ Bioethical commentary has been uniformly hostile to female circumcision, ${ }^{45-49}$ a critique reflected both in the terminology employed and in Anglo-American laws. Both the UK Female Genital Mutilation Act 2003 and the US Federal Prohibition of Female Genital Mutilation Act 1997 are notable for their refusal to countenance any circumstances in which a competent minor girl (or even adult woman in the UK) could choose to be circumcised. Nor are parents permitted to justify the practice on religious or cultural grounds, ${ }^{44}{ }^{50}$ or, in the UK, to take their child abroad for this procedure. ${ }^{51}$ By contrast with such extraordinarily punitive laws, the absence of any statutory regulation governing the practice of male circumcision is striking. ${ }^{8}$

In general, legal commentators have simply assumed that the male/female circumcision binary is self-evident. ${ }^{52}$ Others construe female circumcision as a barbaric violation of human rights, in comparison with which the less radical intervention of male circumcision may be characterised as a legitimate parental choice. ${ }^{53}$ Thus, Coleman argues that any analogy between the two practices

can be and has been rejected as specious and disingenuous [since] traditional forms of FGM [female genital mutilation] are as different from male circumcision in terms of procedures, physical ramifications and motivations as ear piercing is to a penilectomy (p. 736). ${ }^{44}$

To such arguments we would make three rejoinders. First, it is crucial to avoid essentialism; the different types of harm occasioned though the range of practices covered by the terms "circumcision" must be unpacked rather than being represented as "a unitary whole" (p. 151). ${ }^{48}$ Arguably, the less severe forms of female circumcision, such as ritual/ symbolic circumcision (involving the drawing of blood but no permanent tissue damage or scarring $)^{54}$ or sunna (the cutting away of the prepuce of the hood of the clitoris) may be no more severe-or even less severe-than conventional male circumcision, which involves the removal of the foreskin or prepuce covering the glans of the penis..$^{55}$ Clearly the more extreme forms of female circumcision-excision (about 80\% of cases; involves the removal of the clitoris and all or part of the labia minor) and infibulation (about 15\% of cases; involves removal of clitoris, labia minor and at least twothirds of the labia majora, which are then stitched together leaving only a small opening for the passage of urine and menstrual blood) - are radically different in kind from most instances of male circumcision. However, it is worth noting the range of variation in the practice witnessed in other cultures. $^{55}$ 
Such arguments are obfuscated within the BMA guidance, as is particularly evident in the Association's guidance for female genital mutilation. Referring to the less severe practices, the guidance notes that:

Other mutilations include pricking, piercing ... and introduction of ... herbs into the vagina ... The age at which such procedures are carried out varies from a few days old to just before marriage.

All forms are mutilating and carry serious health risks. Female genital mutilation is not comparable with male circumcision, over which there is no consensus about the health risks and potential benefits (p. 1).56

A further problematic distinction that also deploys a particular definition of the word "mutilation" is contained in the Law Commission's report:

It is generally accepted that the removal of the foreskin of the penis has little if any effect on a man's ability to enjoy sexual intercourse, and this act is not, therefore, regarded as a mutilation (para 9.2). ${ }^{26}$

Nevertheless, if variations in the procedures render a simple opposition between male and female circumcision problematic, other commentators have suggested that a more compelling distinction lies in the justifications of the practice. On this view the patriarchal underpinnings of female circumcision, which undermine the right of girls and women to "sexual and corporal integrity", ${ }^{57}$ accounts for much of the revulsion it provokes. Yet we are uneasy with the view that male circumcision is less problematic because it cannot be located in some grand theory of oppression. As our brief outline of its historical emergence highlights, the motivations for and justification of male circumcision are more complex than is often allowed. Like female circumcision, including practices in the UK and the USA into the early twentieth century, it has been used to manage sexuality, and needs to be located within a framework that recognises how it normalises and privileges the male body. In light of this, feminist disinterest in, or acceptance of, the procedure may well be short sighted.

Finally, we would reiterate that artificially contrasting the practices in this way serves only to deflect attention from the more fundamental issue, which has also been obscured in English law, of whether we should be subjecting any children to medically approved procedures involving the excision of healthy tissue. In this regard it is worth remembering that definitions of the prepuce as merely a fold of skin covering the glans have been condemned as grossly simplistic. Rather the prepuce is a complex structure that has a range of significant sexological functions playing "an important role in the mechanical functioning of the penis during sexual acts, such as penetrative intercourse and masturbation" (p. 89). ${ }^{58}$

Given that no clear dichotomy necessarily exists between female and male circumcision, in terms of either the injury inflicted or the motivation for it, we question the lack of will on the part of the medical profession, both institutionally and at the level of some individual practitioners, to challenge the acceptability of the practice. In this respect, attitudes to male circumcision may usefully be contrasted with other areas of health care law, but it is at this point that the arguments of many commentators are seriously flawed, since comparisons chosen often involve adult patients capable of consenting to the procedure. For instance, Benatar and Benatar draw analogies between male circumcision and "other surgical procedures such as breast reduction, liposuction and rhinoplasty", suggesting that, like circumcision of infants, such surgeries are not necessarily "disfiguring" (p. 36). ${ }^{18}$ Similar comparisons with elective procedures freely chosen by adults underpin the reasoning of both the Law Commission ${ }^{26}$ and the majority judgments in $R$. v. Brown. ${ }^{27}$ In our view, more appropriate comparisons that explicitly raise the ethics and legality of exposing infants to the risk of harm would be the enrolment of children in clinical research ${ }^{59}$ or vaccination programmes, ${ }^{60}$ where they are clearly vulnerable to being used for the benefit of others. By contrast with infant male circumcision, in these contexts there is extensive debate about the ethics of consenting to these procedures on behalf of young children, notwithstanding the much greater possibility of benefit to the individual child or other children. The lack of tangible individual or societal benefits accompanying circumcision, coupled with the known risks, makes it surprising that the routine nature of this practice has escaped similar medicolegal controversy. Law's failure to scrutinise adequately the risks inherent in this practice is particularly indefensible, since tort actions in the USA have forced law to confront and quantify the damage that has resulted from negligently performed circumcisions. ${ }^{81-63}$

\section{CONCLUSIONS}

In conclusion, we suggest that two elements characterise the history of non-therapeutic male circumcision: evangelism and the diversity of justifications that evangelical champions of circumcision have mobilised. Although justifications have shifted, they have generally relied on an enduring association between the uncircumcised penis and disease and pollution. ${ }^{64-66}$

Current disputed justifications follow this trend and centre on circumcision as a prophylactic against sexually transmitted disease, including HIV. An assessment of the merits of the scientific research is not our primary concern. In this regard, however, it is worth emphasising Benatar and Benatar's conclusion, following their review of the literature, that none of the scientific evidence "is anywhere near conclusive" (p. 42) ${ }^{18}$ Yet, for some, it is the prevention of HIV/AIDS that legitimates calls for (global) routine male circumcision. In this vein, Roger Short concludes his piece in the JME in a manner consonant with the earlier evangelism. He focuses on circumcision status and the transmission of HIV:

If we believe in evidence-based medicine, then there can be no debate about male circumcision; it has become a desirable option for the whole world. Paradoxically, this simple procedure is a life saver; it can also bring about major improvements to both male and female reproductive health. Rather than condemning it, we in the developed world have a duty to develop better procedures that are neither physically cruel nor potentially dangerous, so that male circumcision can take its rightful place as the kindest cut of all (p. 241). ${ }^{4}$

Such evangelical commitment to circumcision is problematic in a number of respects. First, it ignores the complexity of the existing research and fails to question the utility of global generalisations from a limited number of studies. In terms of sexual health more generally, it fails to address the consequences of claiming circumcision as an effective prophylactic against HIV/AIDS on the transmission of other sexually transmitted diseases. It should be noted that, notwithstanding the high rates of routine circumcision in the USA since at least the 1950s, this country nonetheless has the highest level of sexually transmitted disease and HIV infection in the developed world. ${ }^{67}$ In this regard, in a recent study of male circumcision and the risk of HIV and other 
sexually transmitted infections in India it was recognised that, although circumcised men may have a lower risk of HIV infection, this did not protect them from herpes, syphilis, or gonorrhoea.

This promotion of circumcision as a prophylactic raises wider questions about subjecting children to invasive procedures on the grounds of public health. It is generally accepted that medical intervention is ethically permissible only in response to verifiable disease, deformity, or injury. In addition, the therapeutic intervention must be reasonably believed to result in a net benefit to the patient. While prophylactic interventions are obvious exceptions to this principle, they are justifiable only where deemed to be in the individual's best interests or where aimed at avoiding a significant public health disaster. It has been convincingly agued in this journal that, when a procedure is to be performed on children who are unable to give informed consent, a higher level of scrutiny is demanded. This requires consideration of whether effective and conservative alternative interventions could achieve the intended outcome. ${ }^{23}$ This position underpins the BMA's guidance, which states that it would be unethical to circumcise where medical research has shown other techniques to be at least as effective and less invasive. ${ }^{1}$ Obviously, the provision of condoms and improved sex education are less invasive and more appropriate means of achieving the desired outcome. Although cultural attitudes may make this difficult to achieve in certain communities, public health should not focus on what is attainable in these communities (particularly where this is the most invasive option) for the construction of a global public health strategy. ${ }^{3}$

Circumcision has long existed as a procedure in need of a justification. The most recent focus on sexually transmitted disease-notably with regard to HIV/AIDS-needs to be assessed in light of this. It is our contention that no convincing medical justification for this practice exists. In the absence of unequivocal evidence of medical benefit, we would argue that it is ethically inappropriate to subject a child to the acknowledged risks of infant male circumcision. Having reached this position, the emerging consensus, whereby parental choice holds sway, appears ethically indefensible; nor, given emerging principles and practice governing medical decision making involving children, is there any compelling legal authority for the view that it is lawful.

Rather, in contrast to female circumcision, whose advocates would also point to justifications rooted in culture and cleanliness, law has failed to confront the risks that male circumcision poses to the infant body or to contest the nexus between pain and masculinity. The promulgation of new professional guidance represented an important opportunity to signify that excision of any healthy body parts should neither be left to parental choice nor dependent on the sex of the child. Ultimately, however, the BMA guidelines avoid the issues that should now be at the heart of this debate and represent a missed opportunity.

\section{Authors' affiliations}

M Fox, M Thomson, School of Law, Keele University, Staffordshire, UK

Competing interests: none declared

\section{REFERENCES}

1 British Medical Association. The law and ethics of male circumcision: guidance for doctors. London: BMA, 2003.

2 General Medical Council. Guidance for doctors who are asked to circumcise male children. London: GMC, 1997.

3 Hutson JM. Circumcision: a surgeon's perspective. J Med Ethics 2003;30:238-40

4 Short RV. Male circumcision: a scientific perspective. J Med Ethics 2003;30:241-7.
5 American Academy of Pediatrics, Task Force on Circumcision. Circumcision policy statement. Pediatrics 1999; 103:686-93.

6 Sayre LA. Partial paralysis from reflex irritation, caused by congenital phimosis and adherent prepuce. Trans Am Med Assoc 1870;23:205-11.

7 Hodges FM. The history of phimosis from antiquity to the present. In: Denniston GC, Hodges FM, Milo MF, eds. Male and female circumcision: medical, legal and ethical considerations in pediatric practice. New York: Kluwer Academic, 1999:37-49.

8 Miller GP. Circumcision: cultural-legal analysis. Virginia Journal of Social Policy and the Law 2002;9:497-585.

9 Hutchinson J. A plea for circumcision. BMJ 1890;ii:769.

10 Freeland EH. Circumcision as a preventative of syphilis and other disorders. BMJ 1900;ii:1869-70.

11 Wolbarst AL. Universal circumcision as a sanitary measure. JAMA 1914;62:92-7.

12 Szasz T. Routine neonatal circumcision: symbol of the birth of the therapeutic state. J Med Philos 1996;21:137-48.

13 Gollaher DL. From ritual to science: the medical transformation of circumcision in America. Journal of Social History 1994;28:5-36.

14 Mullen MA. Who speaks for sons? Am J Bioeth 2003;3(2):49-50.

15 Svoboda JS. Circumcision-a Victorian relic lacking ethical, medical, or legal justification. Am J Bioeth 2003;3(2):52-4.

16 Adams B, Beck U, van Loon J. The risk society and beyond: critical issues for social theory. London: SAGE, 2000.

17 Lacey N, Wells C, Quick O. Reconstructing criminal law, third edition. London: Lexus-Nexis, 2003:216-309.

18 Benatar M, Benatar D. Between prophylaxis and child abuse: the ethics of neonatal male circumcision. Am J Bioeth 2003;3(2):35-48.

19 Brazier M. Medicine, patients and the law, third edition. London: Penguin, 2003:350.

20 Warnock F, Sandrin D. Comprehensive description of newborn distress behavior in response to acute pain (newborn male circumcision). Pain 2004; 107:242-55.

21 Williams N, Kapila L. Complications of circumcision. Br J Surg 1993;80:1231-6.

22 Gerharz EW, Haarmann C. The first cut is the deepest? Medicolegal aspects of male circumcision. BJU Int 2000;86:332-8.

23 Hodges FM, Svoboda JS, Van Howe RS. Prophylactic interventions on children: balancing human rights with public health. J Med Ethics 2002;28:10-6.

$24 \operatorname{Re} J$. (a minor) (prohibited steps order: circumcision), sub nom Re J (child's religious upbringing and circumcision) and Re J (specific issue orders, Muslim upbringing and circumcision) [2000] 1 FLR 571; [2000] 1 FCR 307. Butterworth's Medical Law Review 2000;52:82.

$25 \operatorname{Re}$ S. (Children) (Specific issue: circumcision) [2005] 1FLR 236).

26 Law Commission. Consent in the criminal law (Consultation paper 139.) Norwich: The Stationery Office, 1995.

27 R. v. Brown 2 All ER 1993 75, 78-9.

28 Law Commission. Consent in the criminal law (Consultation paper 139.) Norwich: Stationery Office, 1995, para 9.3

29 Per Lord Mustill. In: R. v. Brown 2 All ER 1993 75, 109

30 Smart C. A history of ambivalence and conflict in the discursive construction of the "child victim" of sexual abuse. Social and Legal Studies 1999;8:391-409.

31 Race K. The beast with two backs: bodies/selves/integrity. Australian Feminist Law Journal 1997;9:24-47.

32 Evans DT. Sexual citizenship: the material construction of sexualities. London: Routledge, 1993:209.

33 Binner SL. Effect of parental education on decision-making about neonatal circumcision. Social Medicine Journal 2002;95:457-61.

34 Brown MS, Brown CA. Circumcision decision: prominence of social concerns. Pediatrics 1987:80:215-9.

35 Waldeck S. Social norm theory and male circumcision: why parents circumcise. Am J Bioeth 2003;3(2):56-7.

36 Daniels C. Between fathers and fetuses: the social construction of male reproduction and the politics of fetal harm. Signs 1997;22:579-616.

37 Thomson M. Reproductivity, the workplace and the gendering of the body (politic). Law and Literature 2002; 14:565-94.

38 Beneke T. Proving manhood: reflections on men and sexism. Berkeley, CA: University of California Press, 1997:36. Cited in: Waldeck S. Social norm theory and male circumcision: why parents circumcise. Am J Bioeth 2003;3(2):56-7.

39 Swift J, in R. v. Donovan [1934] 2 KB 498, 508. Cited per Lord Lowry in: R. v. Brown [1993]2 All ER 75, 97

40 Maxwell LG, Yaster M. Analgesia for neonatal circumcision: no more studies, just do it. Arch Pediatr Adolesc Med 1999;153:444-5.

41 Gorman C. Unkindest cut. Time 1999;18(15 Mar):18

42 Research suggests babies should receive anesthetic when circumcised. Jet 1998:93(19 Jan):20.

43 Sheldon S. The masculine body. In: Evans M, Lee E, eds. Real bodies: a sociological introduction. Basingstoke: Palgrave, 2002:14-28.

44 Coleman D. The Seattle compromise: multicultural sensitivity and Americanization. Duke Law Journal 1998;47:717-83.

45 Slack A. Female circumcision: a critical appraisal. Human Rights Quarterly 1988; 10:437-86

46 Brennan $K$. The influence of cultural relativism on international human rights law: female circumcision as a case study. Law and Inequality 1989;7:367-98.

47 Atoki M. Should female circumcision continue to be banned? Feminist Legal Studies 1995; 3:223-35

48 Bibbings L. Female circumcision: mutilation or modification? In: Bridgeman J, Millns S, eds. Law and body politics. Aldershot: Dartmouth, 1995:151-70. 
49 Wood AN. A cultural rite of passage or a form of torture: female genital mutilation from an international law perspective. Hastings Women's Law Journal $2001 ; 12: 347-86$.

50 Sharif KF. Female genital mutilation: what does the new federal law really mean? Fordham Urban Law Journal 1997;24:409.

51 The Prohibition of Female Circumcision Act, 2003. London: The Stationery Office, 2003.

52 Freeman M. A child's right to circumcision. BJU Int 1999;83:74-8.

53 Bridge C. Religion, culture and the body of the child. In: Bainham A, Day Sclater S, Richards M, eds. Body lore and laws. London: Hart, 2002:265-87.

54 Davis DS. Cultural bias in responses to male and female genital surgeries. Am J Bioeth 2003;3(2):W5.

55 Povenmire R. Do parents have the legal authority to consent to surgical amputations of normal, healthy tissue from their infant children? The practice of circumcision in the United States. Journal of Gender, Social Policy and the Law 1999;7:87-123.

56 British Medical Association. Female genital mutilation-caring for patients and child protection: guidance from the Ethics Department. London: BMA 2004:1.

57 Boulware-Miller K. Female circumcision: challenges to the practice as a human rights violation. Harvard Women's Law Journal 1985;8:155-96. Cited in: Coleman D. The Seattle compromise: multicultural sensitivity and Americanization. Duke Law Journal 1998;47:717-83.
58 Taves DR. The intromission function of the foreskin. Med Hypotheses 2002;59:180-2. Cited in: Warren JP. NORM UK and the medical case against circumcision: a British perspective. In: Denniston GC, Milos MF, eds. Sexual mutilations: a human tragedy. New York: Plenum Press, 1997:85-101.

59 Nicolson R. Medical research with children. Oxford: Oxford University Press, 1985.

60 Bridgeman J. The child's body. In: Evans M, Lee E, eds. Real bodies: a sociological introduction. Basingstoke Palgrave, 96-114.

61 Doe v. Raezer 664 A.2d 102 (Pa. Super. Ct. 1995)

62 Felice v. Valleylab, Inc., 520 So. 2d 920 (La. Ct. App. 1987)

63 Graycar R. Sex, golf and stereotypes: measuring, valuing and imagining the body in court. Torts Law Journal 2002;10:205-21.

64 Laumann EO, Masi CM, Zuckerman EW. Circumcision in the United States: prevalence, prophylactic effects and sexual practice. JAMA 1997;277:1052-7.

65 DeHovitz JA. Wrestling with the covenant. West J Med 2000;172:64-5.

66 Fletcher CR. Circumcision in America in 1998: attitudes, beliefs and charges of American physicians. In: Denniston GC, Hodges FM, Milo MF, eds. Male and female circumcision: medical, legal and ethical considerations in pediatric practice. New York: Kluwer Academic, 1999:259-71.

67 Van Howe RS. Circumcision and infectious diseases revisited. Pediatr Infect Dis J 1998;17:1-6.

\section{Notice}

Increasing Ethics, Communication and Social Science Content for Written Exams in Undergraduate Medicine

Hosted by the Universities Medical Assessment Partnership (UMAP), this is a workshop to disseminate good practice in question writing whilst also helping to incorporate ethics, communication, and social science questions into the UMAP bank. This will serve to encourage these topics to be assessed at UMAP partner medical schools who at present include Newcastle, Leeds, Liverpool, Manchester, and Sheffield.

Date: Thursday $24^{\text {th }}$ November 2005

Timings: Workshop 11.00 - 1.30pm; Lunch 1.30pm; Workshop $2.30-5.00 p m$

Place: Gartree and Rutland, $4^{\text {th }}$ Floor, Charles Wilson Building, Leicester University

Presenter: Andrea Owen, UMAP Project Manager

Places are free of charge and can be booked by contacting the UMAP office by email, umap@fs1.with.man.ac.uk or telephone, 0161291 5805. See the project website for more details www.umap.man.ac.uk 